\title{
The Application of Realistic Mathematics Education (RME) Approach to Increase the Creative Thinking Ability of Fraction Subject Matter for Fourth-Graders of SDN Rawajati 06 Pagi
}

\author{
Farida Soraya", Yurniwati, Ucu Cahyana, Mohamad Syarif Sumantri, Adi Apriadi Adiansha \\ Department of Primary Education, State University of Jakarta, Jakarta, Indonesia \\ *Corresponding author: faridasoraya7@gmail.com
}

\begin{abstract}
The Application of Realistic Mathematics Education (RME) Approach to Increase the Creative Thinking Ability of Fraction Subject Matter for Fourth-Graders of SDN Rawajati 06 Pagi. This reseach aims to describe the applying of learning approaches matematics Realistic Education (RME) to improve the ability to think creatively about the concept of fractions. The reseach subjects was 28 students of the fourth grade in Rawajati 06 in academic year 2017/2018. The participants in this study were 2 people, 1 person that acts as a conduit and colleagues 1 as an observer. This study is an action research model of action research (Classroom Action Research). The draft action cycle design intervention study using the model of Kemmis and Taggart with stage planning, acting, observing and reflecting. The experiment was conducted in two cycles, cycle 2 times I held meetings with the material up flat, and the second cycle executed as much as 2 times with the same material in cycle I. This study was conducted in March-April 2018. Data was collected using a post test. The post test techniques with evaluation and observation. Evalution in used to capture data on ability to think creatively about the concept of fractions. While the observations are used to gather data about applyng of learning approaches matematics Realistic Education (RME). Data analysis was performed on data from the study by looking at indicators of success as the result of an agreement between the researcher and observer, the student has achieved as much as $80 \% \mathrm{KKM}$. The result in the first cycle indicates that theaverage student who has reached the KKM in only 57,14\%. The research of the school cycle showed that the average of the tital number of students reached $89,29 \%$ KKM. The result showed that learning by applying of learning approaches matematics Realistic Education (RME) to improve the ability to think creatively about the concept of fractions on the Fourth Grade Students of Rawajati 06 State Elementary School In Academic Year 2017/2018. The implication of the study is that the use of applying of learning approaches matematics Realistic Education (RME) can be done when concept of fractions in learning, if teachers have difficulty in presenting the material and making a low student the ability to think creatively.
\end{abstract}

Keywords: realistic matematics education, creative thinking ability, fraction

Cite This Article: Farida Soraya, Yurniwati, Ucu Cahyana, Mohamad Syarif Sumantri, and Adi Apriadi Adiansha, "The Application of Realistic Mathematics Education (RME) Approach to Increase the Creative Thinking Ability of Fraction Subject Matter for Fourth-Graders of SDN Rawajati 06 Pagi.” American Journal of Educational Research, vol. 6, no. 7 (2018): 1016-1020. doi: 10.12691/education-6-7-19.

\section{Introduction}

Mathematics education is developing in line with the development of world mathematics education. Changes that occur in the process of learning in the classroom, in addition to being influenced by the demands of technological and scientific developments have also often initiated a change of views about the nature of mathematics and learning.

According to As'ari (in Gunawan) the learning of mathematics in Indonesia is still limited to meet the needs of the short-term goal of passing the exam, whether school level, city, provincial or national, mathematics has not been directed to meet the long-term needs where students are only directed to be able to use the formula mathematics without understanding when and how the material is applied in everyday life. [1]

In essence, it deals with abstract ideas. Abstract ideas are still difficult to learn by elementary school students because the stage of thinking is still not formal and still concrete. Primary school students are generally at the age of 7-11 years. According Piaget students aged 7-11 years are on concrete operations.[2] At this stage, the child can only be applied to concrete situations. In everyday life, students find and relate to various problems of real objects related to mathematics.

Given the importance of mathematics in everyday human life, it is necessary to instill the correct concept in 
the learning process. When children learn maths apart from their daily experiences then the child will quickly forget and cannot apply math to real-life situations. Learning activities should be able to engage students to cultivate creative thinking skills and keep students active in the learning process.

Competence of creative thinking for learners is very important in the era of globalization. Creative thinking belongs to high order competencies and can be seen as a continuation of the basic competencies in line with Ervine's statement that creativity plays an important role in the advanced mathematical thinking cycle. According to Career Center Maine Department of Labor USA, the ability to think creatively is also the determinant of a nation's excellence.[3] Competitive power of a nation is determined by the creativity of its human resources.

Based on the research of Utari et al. (in Sumarmo) think and disposition of mathematics and its learning done in class 3, 5, and 6 elementary school obtained by general idea that process of learning mathematics in elementary school, in general, is explanation of material or concept by teacher and student given some routine problem to be done.[4] Turmudi (in Nurjannah) explained that the learning so far is still centered on the teacher.[5]

In fact, the teacher still found the method of lecturing, passive students, questions from students rarely appear, oriented to one correct answer because the learning activities are still dominated by the activities of the exercises for the achievement of basic skills mathematical. Teachers tend to transfer the knowledge that students possess passively and uncritically. Based on the results of interviews with grade 4 students conclude that math lessons are difficult, unattractive, and boring because the teacher only gives the questions at the time of learning and less attention to student learning activities that lead the process of creative thinking.

This is one of the causes of the lack of interest of students in learning mathematics that adversely affect the ability of creative thinking because students are not given the opportunity to seek, ask, answer, reason, and even expressed the opinion during the learning process of mathematics. This resulted in a lack of interaction between students and teachers, where a teacher does not provide space for students to explore mathematical ideas with creative thinking skills characterized by fluent, flexible, original, elaborative, and evaluative thinking skills.

This is evident from the results of fourth graders at SDN Rawajati 06 Pagi, Pancoran District, South Jakarta. The low mathematics learning outcomes are evidenced by the results of the first semester daily Deuteronomy that only reached an average of 61. [6] The result is very low and does not meet the Minimum Criteria of Completeness (KKM) is targeted that is 70. Mathematics as a science is a strong foundation in determining the intelligence of children. As Marks discloses that mathematics at elementary school levels is a crucial foundation in shaping the child's attitude, intelligence and personality.

One approach that can improve the ability to think creatively with the approach Realistic Mathematics Education (RME) in solving a problem in real life means thinking to find ideas or ideas answer to a problem. Hadi argues that learning by applying RME is an approach that is done through exploration of various situations and realistic or real problems that exist around students. [7] The real problems of everyday life are used as the starting point of mathematics learning to show that mathematics is actually close to life.

Therefore, mathematical learning must be related to reality and mathematics as part of human activities. The teacher acts as a student coach to discover mathematical concepts through the process of students' creative thinking skills developed through the RME approach. Students present ideas and ideas in the learning process so that understanding of mathematical concepts and students do not feel mathematics as a difficult lesson but on the contrary, mathematics will be a fun lesson that makes students interested to learn it.

Creative thinking as a necessary capability in various activities to solve the problems that arise in life especially the learning process, thereby expanding the knowledge in finding new ideas. This is in accordance with Krulik \& Rudnik's opinion that creative thinking involves synthesizing ideas, building new ideas, and determining their effectiveness. [8] Creative thinking is characterized by the ability to build new ideas to generate or develop something new.

Munandar says creative thinking (also called divergent thinking) is to provide a variety of possible answers based on information provided with an emphasis on the diversity of numbers and conformity.[9] Coleman and Hammen (in Sukmadinata) described creative thinking is something mental activity to improve the purity (originality), and the sharpness of understanding (insight) in developing something (generating). [10] Both opinions suggest that creative thinking can provide the possibility of diverse answers and activities that result in students' sharp thinking in finding problem-solving.

Creative thinking is defined in a different way according to Jonhson (in Siswono) expressing creative thinking that implies persistence, personal discipline and attention involving mental activities such as asking questions, considering new information and unusual ideas with an open mind, making connections, especially between something similar, relating to one another freely, applying imagination, to each that evokes new and different ideas, and considers intuition.[11] Creative thinking is a mental activity to generate or develop something new.

Torrance above explains creativity consists of four components: (1) eloquence that refers to the continuity of ideas; (2) the flexibility associated with changing ideas; (3) originality characterized by a unique way of thinking; (4) elaboration that refers to the ability to generalize ideas. Of the four components, novelty or originality is widely recognized and viewed as a process related to the generation of original ideas.

A slightly different opinion is expressed by Guilford (in Maulana) that identifies components of creative thinking including fluency, flexibility, originality, elaboration, and also introduces the importance of sensitivity to problems and evaluation in building and evaluating creative ideas. [12] Guilford added that the components of creative thinking are also sensitivity or sensitivity. If summed up, the component of creative thinking consists of fluency, flexibility, originality, flexibility, and sensitivity. The following will explain the components in creative thinking.

Realistic Mathematics Education or realistic mathematics education was born in the Netherlands by Freudenthal 
since 1971. According to Freudenthal, "Realistic Mathematics Education (RME) is an approach in which mathematics education is conceived as human activity". [13] That is, this approach refers to Freudenthal's view that mathematics must be linked to reality, close to the child's experience and relevant to the life of the community. In addition, Freudenthal also holds that mathematics is not seen as a teaching material that must be transferred directly as ready-made mathematics, but must be viewed as a human activity.

In general, the RME approach consists of five characteristics According to Treffers, namely [14]: a) Using real-world contexts, which encapsulate mathematical concepts with the daily experience of the child; b) Using models (mathematization), meaning students make their own models in solving problems; c) Using production and construction, with the production of free production, students are encouraged to reflect on what they consider important in the learning process. Student's informal strategies of contextual problem-solving procedures are a source of inspiration in constructing formal mathematical knowledge; d) Using interaction, explicitly the forms of interaction in the form of negotiation, explanation, justification, agree, disagree, statement or reflection are used to achieve the formal form of informal forms of students; e) Using entertainment, in applying mathematics, usually requires more complex knowledge, and not only arithmetic, algebra, or geometry but also other fields.

Based on RME characteristics according to Treffers and RME principles according to Gravemeijer, and according to Zulkardi the steps of learning mathematics using the RME approach as follows [15]: a) Give students contextual issues related to the topic as a starting point; b) During interaction activities provide instruction to students, for example by drawing a table on the board; c) Guiding students individually or in small groups if they need help; d) Stimulate students to compare their solutions in class discussions. The discussion proceeds on the interpretation of the situation described in the contextual problem and also focuses on the adequacy and efficiency of various solution procedures. Let the students find their own solutions. This means students are free to make discoveries at their own level, to build their own experiential knowledge and do shortcuts with their own density.

Based on problem identification and problem limitation, the problem of this researcher can be formulated as follows: a) Is Realistic Mathematics Education (RME) approachable to improve creative thinking ability of angle measurement material in fourth grade students ?; b) How to improve the creative thinking ability of angle measurement materials with Realistic Mathematics Education (RME) approach in fourth grade students?

The objectives to be achieved in this research is to improve the creative thinking ability of fractional materials using Realistic Mathematics Education (RME) approach on fourth-grade students of SDN Rawajati 06 Pagi Jakarta.

\section{Methods}

This research was conducted at SDN Rawajati 06 Pagi, in class IV located in District Pancoran. The study was conducted at the beginning of the even semester (semester two) of the academic year 2017-2018, at the time of the mathematics course. Subjects in this study were the fourth-grade students of SDN Rawajati 06 Pagi Jakarta, which amounted to 28 students who will provide information on the development of students' creative thinking ability in working group or study group consisting of 16 men and 12 women.

Sources of data in this study are divided into 2 kinds of data sources of action monitoring is a fourth-grade mathematics learning activities conducted at SDN Rawajati 06 Pagi South Jakarta and the source of research data is the ability to think creatively grade IV elementary school.

This research is a class action research conducted in two cycles. Each cycle consists of planning, execution, observation, and reflection. In each action, researchers apply the RME approach with the aim of improving the ability to think creatively especially in the Mathematics lesson on the concept of fractions.

\section{Results and Discussion}

Based on the implementation of the action during 2 cycles conducted 4 meetings, obtained data that the learning process of creative thinking ability of students has increased.

The improved learning process is known by applying RME compiled in systematic steps. Learning involves 4 steps: (1) understanding the contextual problem; (2) solve the contextual problem; (3) modeling; (4) to discuss and conclude. To know the improvement of the learning process is also done by observation to the student, this observation is done by researcher herself. While the improvement of creative thinking ability is known from the comparison of students' creative thinking ability test results for 2 cycles.

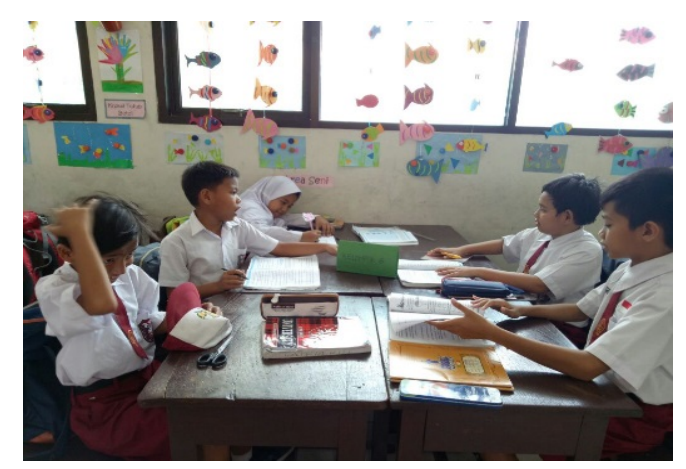

Figure 1. Students understand the group contextual problem in LKS

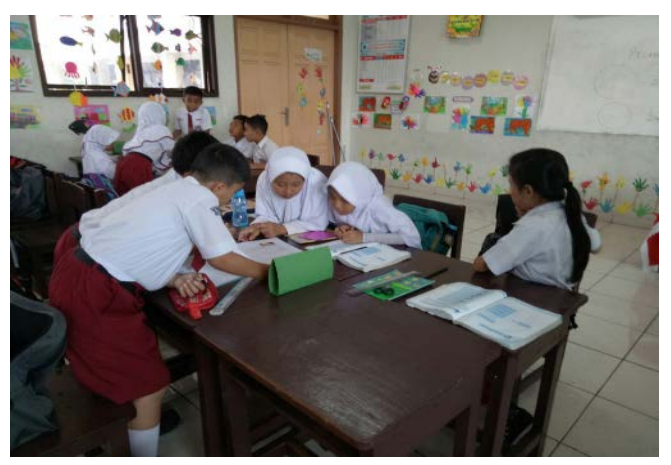

Figure 2. Students solve contextual problems in LKS in groups 


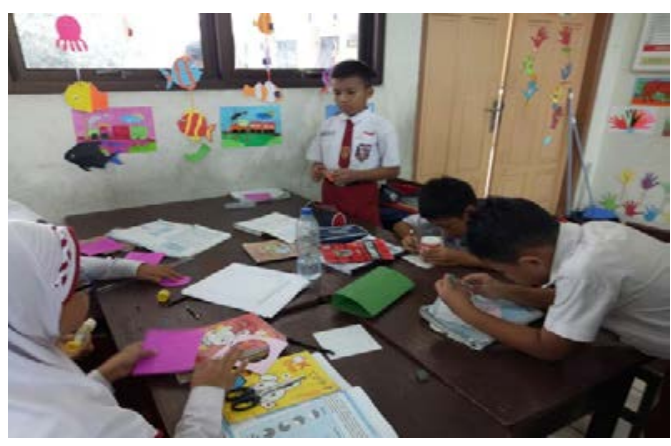

Figure 3. Students contribute to modeling

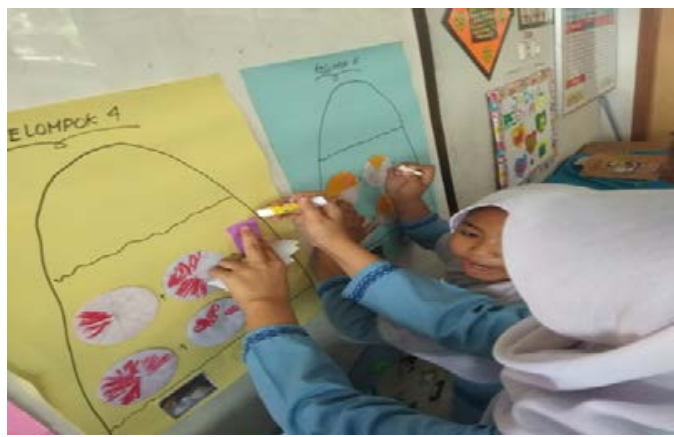

Figure 4. Presenting the results of the discussion

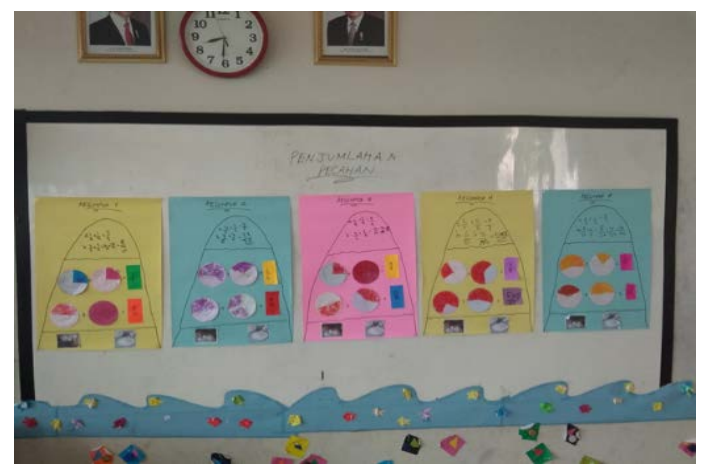

Figure 5. Results of student work

The result of observation on the application of RME in learning can be seen in the following table:

Table 1. Comparison of Observer Monitor Action Observations Using RME Cycle Approaches I and II

\begin{tabular}{|c|c|}
\hline \multicolumn{2}{|c|}{$\begin{array}{c}\text { Action Master uses } \\
\text { RME approach }\end{array}$} \\
\hline Cycle I & Cycle II \\
\hline $77 \%$ & $89 \%$ \\
\hline
\end{tabular}

Table 2. Comparison of Student Action Monitor Observation Results Case I and II RME Approach

\begin{tabular}{|c|cc|}
\hline \multicolumn{3}{|c|}{$\begin{array}{c}\text { Action Master uses } \\
\text { RME approach }\end{array}$} \\
\hline Cycle I & Cycle II \\
\hline $56 \%$ & $89 \%$ \\
\hline
\end{tabular}

Based on the above table, the creative thinking ability of fractional material from cycle I to cycle II increased by $12 \%$ for teacher action monitoring and 33\% for student action monitor, while fractional learning using RME approach through teacher and student action also increased from cycle I to cycle II of $12 \%$ and $33 \%$. Therefore, based on the improvement of creative thinking ability test result and the above action monitor, it can be concluded that fractional learning using RME approach has been achieved.

The result of the creative thinking ability test reached by students also experienced an increase in each cycle. Improved results of students' creative thinking ability tests can be seen in the following tabers;

\begin{tabular}{|c|c|c|c|c|c|c|}
\hline \multirow{2}{*}{ Value } & \multicolumn{2}{|c|}{$\begin{array}{c}\text { The number of } \\
\text { students }\end{array}$} & \multicolumn{2}{|c|}{ Presentation } & \multicolumn{2}{|c|}{ KKM presentation } \\
\hline & Cycle I & Cycle II & Cycle I & Cycle II & Cycle I & Cycle II \\
\hline$>70$ & 10 & 20 & $35,71 \%$ & $71,43 \%$ & \multirow{3}{*}{$\begin{array}{c}57,14 \% \\
\text { Student } \\
\text { s reach } \\
\text { KKM } \\
66,25\end{array}$} & \multirow{3}{*}{$\begin{array}{c}89,29 \% \\
\text { Students } \\
\text { reach } \\
\text { KKM } \\
81,11\end{array}$} \\
\hline$=70$ & 6 & 5 & $21,43 \%$ & $17,86 \%$ & & \\
\hline$<70$ & 12 & 3 & $42,86 \%$ & $10,71 \%$ & & \\
\hline
\end{tabular}

Based on the above table it can be seen that the average score starting from the initial condition until cycle 2 has increased. At cycle condition, I student score 66,25 in the second cycle rose to 81,11 . While the percentage of students' ability to think creatively have an increase of cycle I 57.14\% and cycle II 89.29\%.

\section{Conclude}

Based on the results of research and discussion that has been presented in the previous section, it can help the conclusion: (1) RME learning approach can improve the ability of creative thinking in fourth grade students of SDN Rawajati 06 Pagi In 2017/2018 Lesson year, especially on fractional subject; (2) By implementing 4 learning steps covering contextual problem, solving contextual problem, making model, answer and answer according to RME, able to improve the quality of learning in SDN Rawajati 06 Pagi especially in Mathematics lesson about fractional concept in Lesson year 2017/2018; (3) The advantages of RME are able to improve the ability of creative thinking, able to increase activity, creativity and communication skills to answer, able to integrate daily problems in the problem, student centered, students have freedom in construing knowledge and understanding which are owned; (4) The weakness of RME is a very long time and can be used for the learning process, teachers determine for each participant.

Based on the results of this study, it is expected that teachers need to apply RME in implementing mathematics learning because it can embed the concept or principles contained in the learning with problems commonly encountered students in everyday life. Teachers also need to use methods and media in implementing learning, learning math, and the ability to learn creatively.

\section{References}

[1] Gunawan, “The Ability of Mathematical Reasoning” (accessed November 17, 2014).

[2] Deswita, Developmental Psychology (Bandung: PT Remaja Rosdakarya, 2005).

[3] Ali Mahmdi, "Measuring the Ability of Mathematical Creative Thinking” (National Conference Mathematics XV: UNIMA, 2010). 
[4] Utari Sumarmo, "Character Education as well as Development of Thinking and Mathematical Disposition in Mathematics Learning” (Mathematics Education Seminar: NTT, 2012).

[5] Nurjannah, "Contextual Learning to Improve Problem Solving Abilities (Metacognitive Aspects) and Communication Skills of Elementary Student Mathematics” (Thesis: Universitas Pendidikan Indonesia, 2013)

[6] Recapitulation of Deuteronomy Value First Semester (Jakarta: SDN Rawajati 06 Pagi, 2017).

[7] Hadi, Realistic Mathematics Education and Implemantasinya (Banjarmasin: Tlip, 2005).

[8] Krulik, and Rudnick, "The New Sourcebook for Teaching Reasoning Problem Solving in Elementary School” (Heights: Allyn \& Bacan, 1995).

[9] Utami Munandar, Creative Development of Gifted Children (Jakarta: Rineka Cipta, 2009).

[10] Sukmadinata, Curriculum and Competency Learning (Bandung: Kusma Karya, 2004)
[11] Siswono, "Identifying the Process of Student Creative Thinking in Problem Solving in Guided Mathematics with Walls and Creative Problem Solving (CPS) Model” (Journal: Mathematics Education, 2004).

[12] Maulana, Mathematical creative thinking, which is necessary! (think creative mathematically, it is necessary!), (Journal Indonesian University of Education campus: Sumedang, 2012).

[13] Hans Freudenthal, "Mathematics as an Educational Task" (Dordrecht: Reidel Publishing).

[14] Evi Sovianti, "Realistic Mathematics Approach (PMR) To Improve Student Thinking Ability in Primary School Level” (Journal: SPS UPI, 2011).

[15] Zulkardi, "Designing, Evaluating And Implementing An Innovative Learning Enviroinment For Supporting Mathematics Education Reform In Indonesia” (The CASCADE-IMEI Study, 2000). 